\title{
STOMACH
}

\section{Modulation of host antimicrobial peptide ( $\beta$-defensins 1 and 2) expression during gastritis}

\author{
M Bajaj-Elliott, P Fedeli, G V Smith, P Domizio, L Maher, R S Ali, A G Quinn, \\ M J G Farthing
}

See end of article for authors' affiliations

.....................

Correspondence to: M Bajaj-Elliott, Department of Adult and Paediatric Gastroenterology, St Bartholomew's and the Royal London School of Medicine and Dentistry, Turner St, London El 2AD, UK

M.Bajaj-Elliot+@qmul.ac.uk

Accepted for publication 18 December 2001

\begin{abstract}
Background: $\beta$-Defensins are a newly identified family of antimicrobial peptides that are expressed by epithelia on mucosal surfaces where their production is augmented by infection or inflammation. Helicobacter pylori colonises the gastric epithelium causing persistent gastric inflammation leading to antral and corpus gastritis, and peptic ulcer disease.

Aims: To evaluate the role of $\beta$-defensins in the innate immune response of the gastric epithelium to infection and inflammation, we have assessed mRNA expression and regulation of human $\beta$-defensins 1 and 2 (hBD1, hBD2) by $\mathrm{H}$ pylori and proinflammatory stimuli. We have also compared gene and peptide expression of these bactericidal agents in $H$ pylori induced gastritis with that in normal gastric mucosa.

Methods: Modulation of expression of hBD1 and hBD2 by various stimuli was studied in three (AGS, MKN7, MKN45) gastric epithelial cell lines by quantitative competitive reverse transcriptionpolymerase chain reaction (RT-PCR). Defensin mRNA expression was measured by semiquantitative RT-PCR in gastritis tissue and compared with controls. Peptide localisation was assessed by immunohistochemistry.

Results: Cytotoxic $H$ pylori and interleukin $1 \beta$ (IL-1 $\beta$ ) markedly upregulated expression of hBD2 in a dose and time dependent manner in both AGS and MKN7 cell lines. A modest increase in hBD1 expression was also noted during infection. Interestingly, induction of hBDl gene expression by IL-1 $\beta$ was only observed in MKN7 cells. The magnitude of this response was delayed and reduced compared with hBD2 expression. In gastric biopsies, hBD2 was undetectable in normal gastric antrum but a marked increase was observed in $H$ pylori positive gastritis compared with control tissue $(p<0.001)$. Constitutive expression of $\mathrm{hBD} 1$ was observed in normal gastric mucosa and there was a significant increase in gastritis $(p<0.05)$. Immunohistochemistry revealed a parallel increase in hBD 1 and hBD2 peptide expression in gastritis tissue with positive staining confined to the surface epithelium of the gastric glands.

Conclusions: Modulation of $\beta$-defensin expression by pathogenic and/or inflammatory stimuli and their cellular localisation places these antimicrobial peptides in the front line of innate host defence in the human stomach.
\end{abstract}

$\mathrm{n}$ various pathophysiological conditions such as inflammation and infection, the epithelium, together with intraepithelial lymphocytes and lamina propria immune cells, coordinate local innate and adaptive immune responses at both sensory and effector levels. ${ }^{12}$ Helicobacter pylori is a gram negative bacterial pathogen that infects the stomach, exhibiting tropism for human gastric epithelium. ${ }^{3}$ The bacterium attaches, colonises the gastric mucosa, and elicits both cellular and humoral immune responses. ${ }^{4-6} H$ pylori associated gastroduodenal diseases are characterised by inflammation of the mucosa accompanied by massive recruitment of activated immune cells (particularly neutrophils) to the lamina propria. There is a general consensus that the resulting host tissue damage observed is due to the combined effects of both bacterial virulence factors and host inflammatory mediators. ${ }^{7-9}$

In recent years two members of a new family of antimicrobial peptides, $\beta$-defensins, have been identified and shown to be expressed by epithelia of various mucosal surfaces where their production is augmented by infection or inflammation. ${ }^{10-14}$ Human $\beta$-defensin 1 (hBDl) is constitutively expressed in epithelia and preliminary biochemical analyses suggest the peptide may exists in various isoforms; this is primarily due to differential processing of the amino terminus of its precursor molecule. ${ }^{13}$ At present the antimicrobial potential of these individual isoforms of hBDl remains unclear. Several studies have also shown that unlike
hBDl, the second member of this family $\beta$-defensin 2 (hBD2) is only expressed during inflammatory and infectious episodes. ${ }^{15}{ }^{16}$ Previously, Wada et al showed increased expression of hBD2 by $H$ pylori in the MKN45 gastric epithelial cell line and this effect was found to be dependent on the presence of the cag pathogenicity island in the bacterial genome. ${ }^{17}$ More recently, O'Neil et al have also shown upregulation of hBD2 by $H$ pylori in the AGS gastric epithelial cell line. ${ }^{18}$

To further our understanding of the mechanism(s) involved in the host defence to $H$ pylori and the potential role of these peptides during infection and inflammation, we have further studied regulation of hBDl and hBD2. Our in vitro studies show for the first time that mRNA expression of hBDl is not only constitutive but can be further modulated during infection. We have also confirmed marked upregulation of hBD2 by $H$ pylori and cytokine stimuli. To test the hypothesis that hBD1 and hBD2 are involved in the mucosal response to Helicobacter, we further assessed expression of these genes in $H$ pylori induced gastritis tissue. We observed a significant

Abbreviations: hBD, human $\beta$-defensin; IL, interleukin; IFN- $\gamma$, interferon

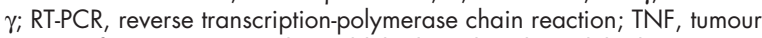
necrosis factor; GAPDH, glyceraldehyde-3-phosphate dehydrogenase; $\mathrm{MOI}$, multiplicity of infection. 
increase in hBDl and hBD2 mRNA and peptide expression in gastritis compared with control tissue. Our present study suggests that surface expression of hBDl and hBD2 may form a critical component of the host innate defence to potential noxious stimuli in the human stomach.

\section{MATERIALS AND METHODS \\ Cells and reagents}

The human gastric cell lines AGS, MKN7, and MKN45 were maintained in RPMI 1640 culture medium supplemented with $10 \%$ heat inactivated fetal calf serum (FCS; Sigma, Poole, UK), $2 \mathrm{mM}$ L-glutamine, 100 units/ml penicillin, $100 \mathrm{\mu g} / \mathrm{ml}$ streptomycin, and $1 \%$ non-essential amino acids (Life Technologies, Paisley, UK). Cells $\left(1 \times 10^{5}\right)$ were seeded into $25 \mathrm{~cm}^{2}$ area flasks and maintained at $37^{\circ} \mathrm{C}$ in $5 \% \mathrm{CO}_{2}$.

\section{$\boldsymbol{H}$ pylori culture and cytokine stimulation protocols}

H pylori strain NCTC 11637 (CagA/VacA positive) was grown on blood agar base 2 plates supplemented with $5 \%(\mathrm{v} / \mathrm{v})$ horse blood (Oxoid, Basingstoke, UK) for three days under microaerobic conditions (Campy-Pak Systems; BBL, UK). Prior to use, the bacteria were resuspended in phosphate buffered saline and quantified by measurement of optical density at $450 \mathrm{~nm}$. For bacterial/epithelial coculture experiments, the confluent epithelial cell layer was maintained in RPMI 1640 media as before, without antibiotics.

For cytokine stimulation experiments, the confluent cell layer was maintained in serum free $(0.5 \%$ fetal calf serum) media for 16 hours before addition of various cytokines. Recombinant interleukin (IL)-1 $\beta$, tumour necrosis factor $\alpha$ (TNF- $\alpha)$, interferon $\gamma($ IFN- $\gamma)$, and IL-17 were obtained from R\&D Systems (Abingdon, UK).

\section{Patients and tissues}

This study was approved by the Research Ethics Committee of the East London and City Health Authority. For reverse transcription-polymerase chain reaction (RT-PCR) analysis, mucosal antral biopsies were obtained from patients with histologically proved active gastritis $(\mathrm{n}=10, \mathrm{H}$ pylori positive) and 12 control patients endoscoped for symptoms of non-ulcer dypepsia or reflux in whom biopsies showed no significant histological abnormality. Biopsies were immediately snap frozen and stored at $-70^{\circ} \mathrm{C}$. Patients who had received anti-inflammatory, immune modulating, or antisecretory drugs in the previous month were excluded. H pylori infection was determined by biopsy urease test (CLOtest) and by histological examination of tissue samples using cresyl-fast violet staining as well as routine haematoxylin and eosin staining.

\section{RNA standard for quantitative RT-PCR}

To allow quantification of hBDl and hBD2 mRNA expression by RT-PCR, we constructed a plasmid that encodes a standard RNA molecule. Sequence specific primers used in the study were as follows: hBDl sense primer $\left(5^{\prime 109}\right.$ TTGTCTGAGATGGCCTCAGGTGGTAAC $\left.{ }^{136} 3^{\prime}\right)$; hBDl antisense primer $\left(5^{\prime}{ }^{362}\right.$ ATACTTCAAAAGCAATTTTCCTTTAT ${ }^{337} 3^{\prime}$ ); hBD2 sense primer $\left(5^{\prime \prime 1}\right.$ CCAGCCATCAGCCATGAGGGTCTT $\left.{ }^{34} 3^{\prime}\right)$; and hBD2 antisense primer $\left(5^{\prime 287}\right.$ CATGTCGCACGTCTCTGATGAGGGAGC ${ }^{261}$ $\left.3^{\prime}\right)$.

The above primer sequences were cloned into plasmid pMBEK as described in detail previously. ${ }^{19}$ To generate standard RNA, the plasmid was linearised with Hind III and transcribed in vitro using T7 RNA polymerase under conditions recommended by the supplier (Promega, Southampton, UK). Using the same primer set, RT-PCR for hBDl yielded a standard PCR product of $434 \mathrm{bp}$ whereas the target size was 253 bp. Similarly, the size difference between the standard hBD2 PCR product (486bp) versus the target tissue PCR product $(276 \mathrm{bp}$ ) allowed quantification (number of mRNA transcripts/pg total cellular RNA) of each of the $\beta$-defensins.
Semiquantitative RT-PCR was carried out on the gastric biopsy samples. Expression of hBDl and hBD2 was normalised to expression of the housekeeping gene glyceraldehyde-3phosphate dehydrogenase (GAPDH). GAPDH primers used in this study were: sense primer $5^{\prime 630}$ CTACTGGCGCTGGCAAGGCTGT $^{651} 3^{\prime}$ and antisense primer $5^{\prime 989}$ GCCATGAGGTCCACCACCCTGCTG ${ }^{966} 3^{\prime}$.

\section{RNA isolation and PCR amplification}

All reagents for RNA extraction and RT-PCR analysis were obtained from Life Technologies. Total RNA isolation from cells (AGS, MKN7, and MKN45) and mucosal gastric biopsies were performed using a monophasic solution of phenol and guanidine thiocyanate (TRIzol), as recommended by the suppliers. Serial 10-fold dilutions of the standard ( $1 \mathrm{ng}$ to $100 \mathrm{fg}$ ) were cotranscribed with total cellular RNA $(\sim 5 \mu \mathrm{g})$ to generate cDNA using Moloney murine leukaemia virus reverse transcriptase. PCR was routinely performed using 0.5 units of Taq polymerase, $20 \mathrm{pmol}$ of each oligonucleotide primer, 1.5 $\mathrm{mM} \mathrm{MgCl}$, and $200 \mu \mathrm{M}$ deoxynucleotide triphosphates in a final reaction volume of $50 \mu \mathrm{l}$. The amplification cycle was as follows: $94^{\circ} \mathrm{C}$ denaturation for 90 seconds; $58^{\circ} \mathrm{C}$ annealing for 90 seconds; and $72^{\circ} \mathrm{C}$ extension for 90 seconds; for 37 cycles. Following amplification, the PCR products were analysed on $2 \%$ agarose gels and band intensities were quantified by densitometry (Kodak Digital Science Electrophoresis Documentation and Analysis System 120; Life Technologies). The ratios of band intensities of the PCR products from the standard RNA and target RNA were plotted against the starting number of standard RNA molecules on a double logarithmic scale. In this way, the point at which the starting number of standard RNA transcripts is equal to the starting amount of cellular target RNA can be determined. This technique allows us to quantify the number of mRNA transcripts in a sample to a sensitivity of $10^{3}$ molecules/pg total RNA.

Semiquantitative RT-PCR was performed on biopsy specimens. cDNA was prepared from the samples as described above and the product was divided into three aliquots. PCR for hBD1, hBD2, and the housekeeping gene GAPDH was terminated after 37 cycles of amplification where we obtained optimum product yield in the linear phase of the reaction. The resulting products were analysed as above.

\section{Immunohistochemistry}

Immunohistochemistry was performed on archival paraffin blocked full thickness samples of resection tissue and biopsies from patients with varying grades of gastritis. Dewaxed and rehydrated $4 \mu \mathrm{m}$ sections were initially incubated for $15 \mathrm{~min}$ utes in a $3 \% \mathrm{H}_{2} \mathrm{O}_{2} /$ methanol mix to inhibit endogenous peroxidase activity. For both hBDl and hBD2 staining, antigen retrieval was performed by microwaving sections in $0.1 \mathrm{M}$ citrate buffer at pH 6.0 for 30 minutes before further incubation with neat horse serum for 15 minutes in order to reduce nonspecific binding. Sections were incubated with primary polyclonal antibodies for hBDl and hBD2 (raised in rabbit) at 1:800 dilution overnight at $4^{\circ} \mathrm{C}^{20}$ Both positive (skin tissue) and negative (without primary antibody) controls were also included. After appropriate washes, the sections were incubated with biotinylated antirabbit IgG antibody, followed by avidin-peroxidase complex for 30 minutes at room temperature. Visualisation was performed using the 3, 3'diaminobenzidine method. All reagents used in the above procedure were purchased from Vector Laboratories Ltd (Peterborough, UK).

\section{Statistical analysis}

Comparison of hBDl and hBD2 mRNA expression among the various groups of patients was performed using the MannWhitney U test. 

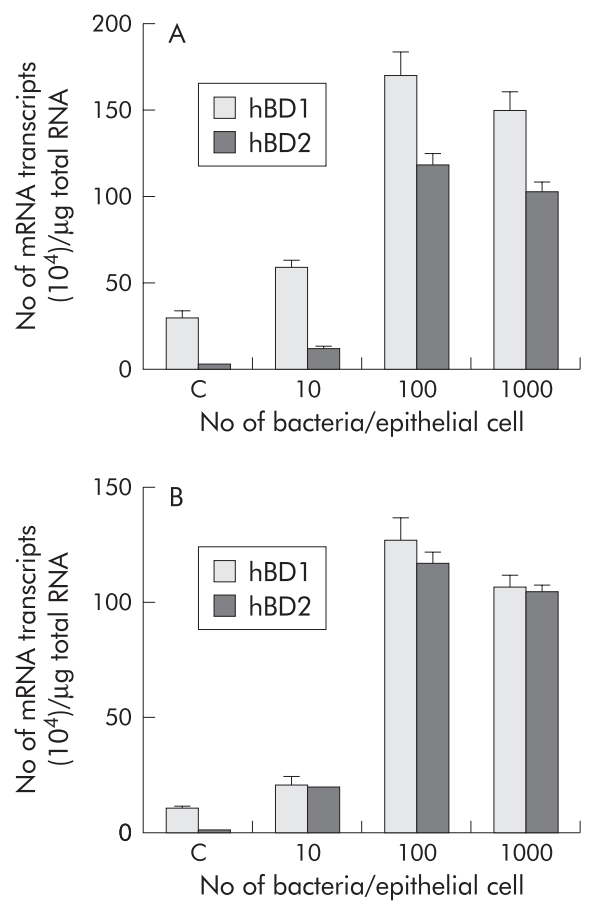

Figure 1 Dose dependent increase in human $\beta$-defensin 1 and 2 (hBD1, hBD2) mRNA expression in AGS (A) and MKN7 (B) cell lines with Helicobacter pylori NCTC 11637 strain. Cells were infected for 24 hours at $37^{\circ} \mathrm{C}$. Results are mean (SEM) of four independent experiments. A significant increase $(\mathrm{p}<0.001)$ in $\mathrm{hBD} 1$ and $\mathrm{hBD} 2$ mRNA expression was observed on infection at a multiplicity of infection of 100 .

\section{RESULTS}

A dose dependent increase in hBDl mRNA expression with increasing number of infecting organisms was observed in both AGS (fig 1A) and MKN7 (fig 1B) cell lines over a 24 hour incubation period. Constitutive expression of hBDl was sixfold lower in MKN7 cells compared with the AGS cell line. Irrespective of this basal difference, the increase in hBDl mRNA expression levels by $H$ pylori was found to be similar in both cell lines. The maximum level of expression was observed at a multiplicity of infection (MOI) of 100. A representative quantitative RT-PCR gel showing increased hBDl mRNA expression with increasing MOI is shown in fig 2. No hBD2 was detected in control cells but on infection with the bacterium there was a significant increase in hBD2 mRNA expression, even at low MOI ( 10 bacteria/cell). Similar high levels of hBD2 expression were achieved in each cell line. On maximal stimulation there was no significant difference between expression levels of hBDl and hBD2. Interestingly, hBDl and hBD2 expression was found to be constitutive and high $\left(>10^{7}\right.$ transcripts/pg total RNA) in MKN45 cells (data not shown), suggesting dysregulation of defensin gene expression in this cell line.

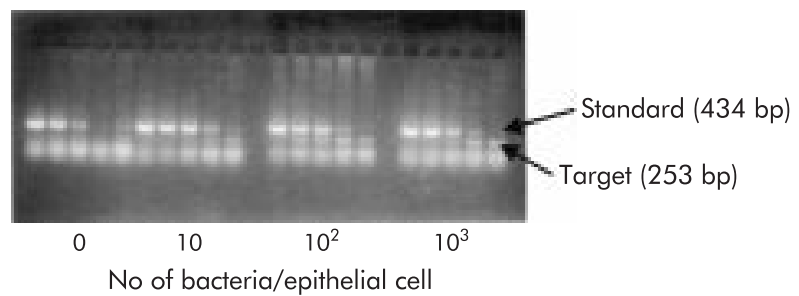

Figure 2 A representative quantitative reverse transcription-polymerase chain reaction gel illustrating induction of human $\beta$-defensin 1 (hBD I) mRNA expression (that is, target band) with increasing multiplicity of infection in MKN7 cells.

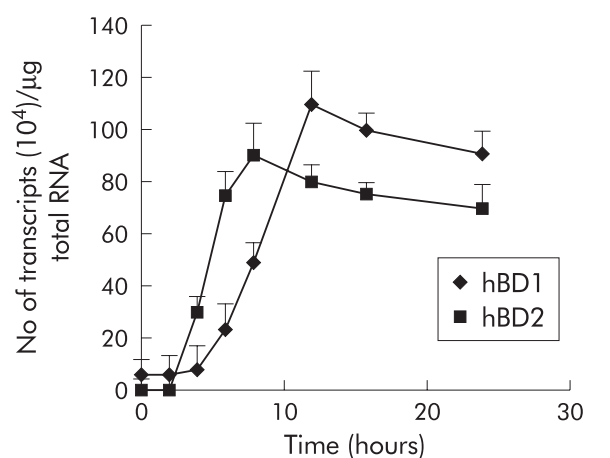

Figure 3 Time dependent increase in human $\beta$-defensin 1 and 2 (hBD 1, hBD2) mRNA expression by Helicobacter pylori. MKN7 cells were coinfected at a multiplicity of infection (MOI) of 100 for 24 hours. hBD2 upregulation was initially noted at three hours with a maximum increase observed at eight hours. hBD1 mRNA expression was much slower with a maximum increase observed at 12 hours. Results are mean (SEM).

Due to the low constitutive expression of hBDl in MKN7 cells, this cell line was chosen for further analyses. The kinetics of induction of hBDl and hBD2 were studied at an MOI of 100 , as this ratio of infectivity was found to be most potent, as shown above. Time course experiments showed that expression of hBD2 began 3-4 hours after infection (fig 3), then markedly increased to attain maximal expression at eight hours, followed by declining levels at 12 and 24 hours. In contrast, induction of hBDl mRNA expression was much slower than that for hBD2 with the first increase observed at eight hours and maximum expression occurring at 12 hours post-infection.

\section{IL-1 $\beta$ increases expression of hBD1 and hBD2 in MKN7 cells}

Several previous studies have shown that proinflammatory cytokines such as IL- $1 \beta$ and TNF- $\alpha$ can increase $\beta$-defensin expression. ${ }^{15}{ }^{21}$ We have also examined the effect of a panel of proinflammatory cytokines (IL-1 $\beta$, TNF- $\alpha$, IFN- $\gamma$, IL-17) on hBDl and hBD2 mRNA expression in MKN7 cells. Among the cytokines tested, IL-1 $\beta(5 \mathrm{ng} / \mathrm{ml})$ was found to be the only stimulant for hBDl and hBD2 in this cell line. As observed during infection with $H$ pylori, IL- $1 \beta$ also caused an increase in hBDl and hBD2 mRNA expression in a time dependent manner, with a similar earlier maximal increase in hBD2 expression ( 12 hours $v 16$ hours for hBDl; fig 4). However, the magnitude of induction of both peptides was much less and

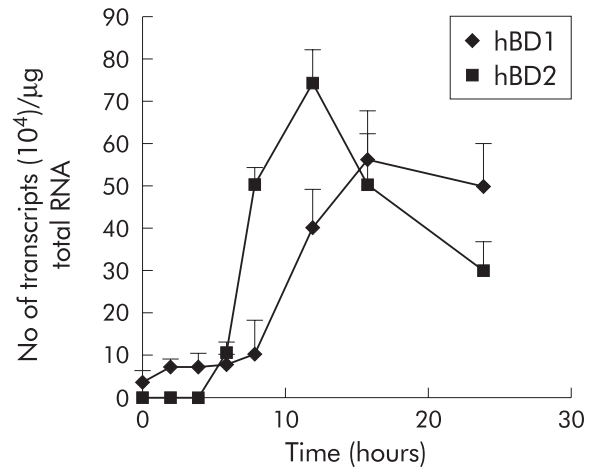

Figure 4 Interleukin $1 \beta$ (IL-1 $\beta)$ is a stimulant of human $\beta$-defensin 1 and 2 (hBD1, hBD2) mRNA expression. MKN7 cells were incubated with IL-1 $\beta(5 \mathrm{ng} / \mathrm{ml})$ for 24 hours. As seen in fig 2, the kinetics of the increase in hBD2 expression were more rapid than for hBD 1. The magnitude of response was much lower than that observed with Helicobacter pylori. 

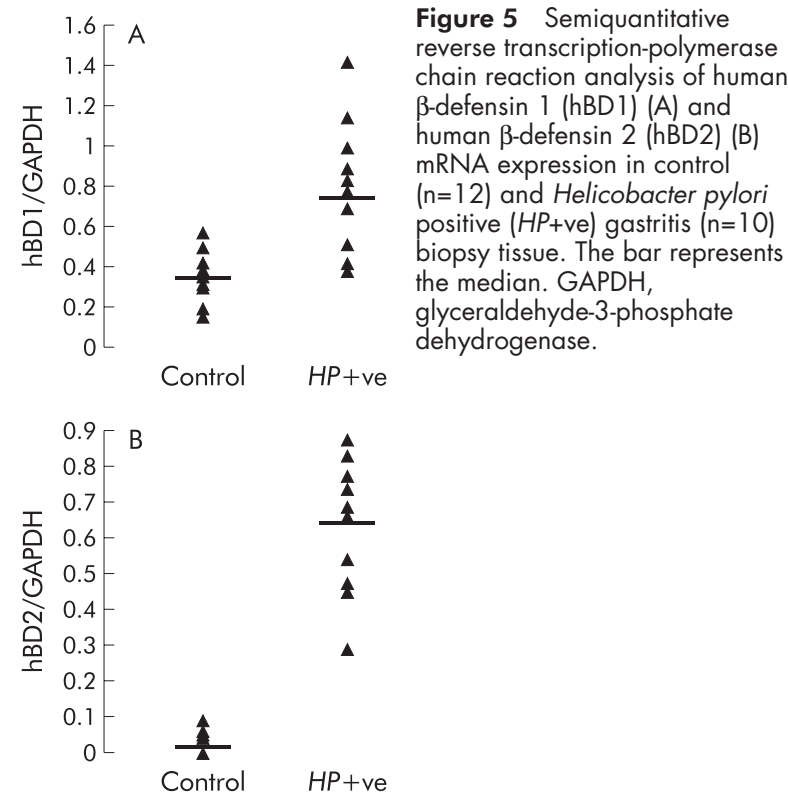

delayed in IL- $1 \beta$ treated cells when compared with $H$ pylori infected cells.

\section{In vivo expression of $\mathrm{hBD} 1$ and $\mathrm{hBD} 2$}

To resolve the potential effect of $H$ pylori colonisation on hBDl and hBD2 mRNA expression in the gastric mucosa, semiquantitative RT-PCR analyses was performed on biopsies from patients with gastritis and compared with control tissue (fig 5A, B). Control biopsies showed constitutive expression of hBD1 whereas hBD2 mRNA was undetectable. Expression of hBD2 was markedly upregulated in $H$ pylori positive gastritis $(\mathrm{p}<0.001)$. Upregulation of hBDl also achieved statistical significance $(\mathrm{p}<0.05)$ in gastritis compared with control tissue.

To further confirm increased expression of hBDl and hBD2 in the gastric epithelium of $H$ pylori positive gastritis, immunohistochemistry was performed on archival paraffin sections of gastric biopsy specimens. Increased positive staining for hBDl and hBD2 peptide expression was observed in gastritis (fig 6C, D) compared with control tissue (fig 6A, B). Staining was confined to the surface epithelium and the gastric pits of the gastric gland, with no staining detected in the lamina propria or in inflammatory cells of the gastric mucosa.

\section{DISCUSSION}

Helicobacter pylori plays a major role in the pathogenesis of chronic antral gastritis and peptic ulcer disease. ${ }^{22}$ There is accumulating evidence that both bacterial factors and subsequent host defence responses contribute to the ongoing inflammatory processes that determine the clinical manifestations of the disease.

During infection, detection of chemokines (C-C and C-X-C) and early recruitment of neutrophils in the gastric mucosa are indicative of the active participation of innate immune mechanisms. ${ }^{23-25}$ In the present study, we have expanded the repertoire of the innate immune responses by the host to Helicobacter infection. Studies to date have shown constitutive expression of hBDl by various mucosal surface epithelia, suggesting a "surveillance-like" role for this peptide in maintaining tissue homeostasis in the absence of infection. ${ }^{10}$ In the present study, we show that the constitutive expression of hBDl can be further modulated during infection and inflammation. Dale et al have also recently noted similar modulation of hBDl expression in inflamed periodontal tissue. ${ }^{26}$ These two studies to date therefore imply a greater role for hBDl in innate host defence than was previously thought. At present,
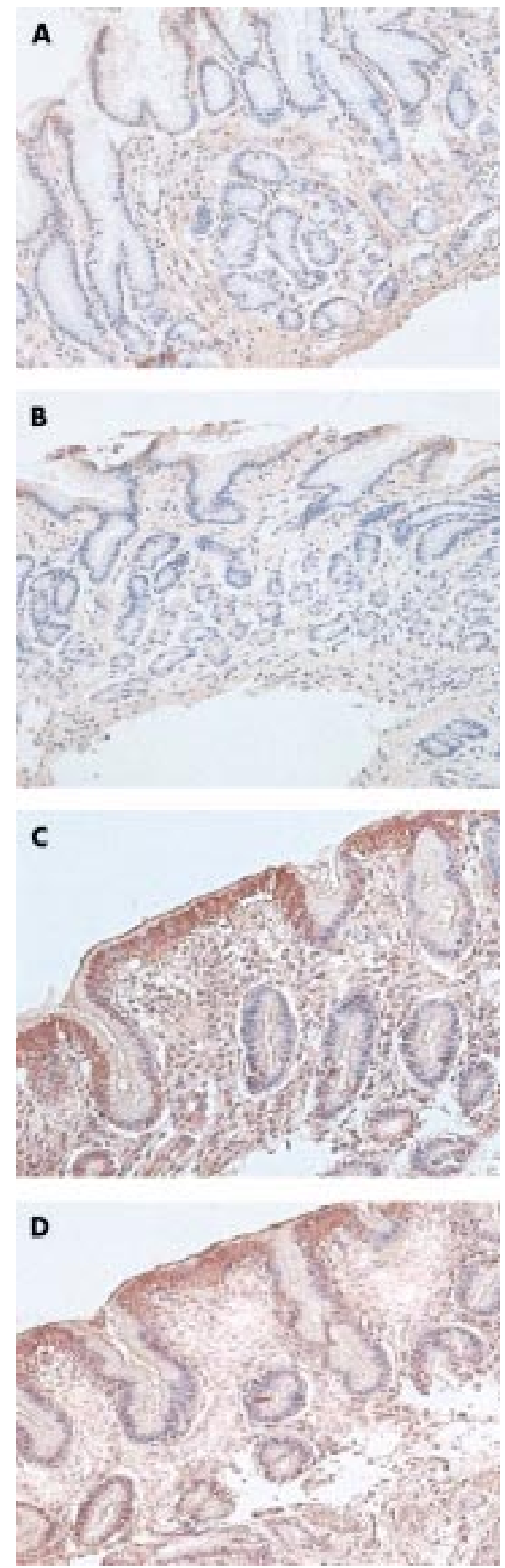

Figure 6 Detection of $\beta$-defensins by immunohistochemistry. (A) (human $\beta$-defensin 1 (hBD 1)) and (B) (human $\beta$-defensin 2 (hBD2)) show control gastric mucosa with very faint staining for both peptides. (C) and (D) (Helicobacter pylori positive gastritis) show positive staining for hBD 1 and hBD2 peptides, respectively, in the surface epithelium and in gastric pits.

regulation of hBDl gene and peptide expression during infectious and inflammatory episodes remains unclear. Using the sensitive technique of competitive RT-PCR, we observed induction of hBDl mRNA expression in AGS and MKN7 cells 24 hours after infection with $H$ pylori. We observed great variation in basal expression of hBDl in different gastric epithelial cell lines. For example, initial experiments conducted in MKN45 cells showed a spontaneous high level expression of 
hBDl and hBD2 in unstimulated cells which was not modulated by the bacterium. O'Neil et al have recently reported no change in constitutive expression of hBDl in AGS cells by H pylori (MOI of 10).$^{18}$ In contrast, our coculture infection experiments were conducted at a greater multiplicity of infection (MOI 100), and the initial increase in hBDl expression was first detected only at eight hours. The combined effect of variation in basal hBDl levels in different cell lines, bacterial strains, and variable numbers of infecting organisms may partly explain the results obtained in different laboratories.

Unlike hBD1, hBD2 peptide is not expressed by epithelia in the absence of infection. As expected, no hBD2 was detected in control cell lines and in control gastric biopsy tissue. We have confirmed upregulation of hBD2 mRNA by $H$ pylori, as reported previously. ${ }^{17}{ }^{18}$ In time course studies, we observed marked upregulation of hBD2 expression as early as three hours post-infection in MKN7 cells. The kinetics of hBDl induction in comparison were much slower as the first increase was noted only at eight hours post-infection. At present, the identity of both bacterial virulence factors and host signalling events involved in the induction of defensin expression is limited. Although a crucial role for the bacterial "cag pathogenicity island" in induction of hBD2 mRNA expression has been observed, ${ }^{17}$ its potential role in the regulation of hBDl expression has not been studied to date. Wada et al have recently shown unequivocally the involvement of the transcription factor nuclear factor $\mathrm{kB}$ in induction of hBD2. ${ }^{27}$ In contrast, no nuclear factor $\kappa \mathrm{B}$ binding sites have been identified in the promoter sequence of hBDl. ${ }^{28}$ The molecular mechanism(s) that may play a part in the activation of these peptides requires further investigation.

Several studies have shown that proinflammatory cytokines such as IL- $1 \beta$ and TNF- $\alpha$ can directly increase expression of mammalian defensins. ${ }^{15}{ }^{18}{ }^{21}$ In the present study, we explored the effects of various cytokines on expression of hBDl and hBD2 in gastric epithelial cell lines and found IL-1 $\beta$ to be a potent stimulant of hBD2 in all three gastric cell lines tested. In contrast, the effect of IL-1 $\beta$ on hBDl expression was only observed in MKN7 cells with no induction in AGS and MKN45 cells. It is probable that the high basal levels of hBDl observed in AGS and MKN45 cell lines may contribute to masking of cytokine response. Interestingly, two previous studies have reported no effect of IL- $1 \beta$ on hBDl expression. ${ }^{18}{ }^{29}$ As different cancer cell lines were used in the various studies, the data taken together suggest that the degree of cellular differentiation may play a role in $\beta$-defensin gene regulation. Recent studies by El-Omar et al have suggested that the presence of IL-1 gene cluster polymorphism in susceptible individuals is associated with an increased risk of $H$ pylori induced hypochlorhydria and gastric cancer. ${ }^{30}$ At present, the role of $\beta$-defensins during inflammatory episodes is unclear but specific induction by IL-1 $\beta$ may have major consequences in the innate host-defence response to bacterial colonisation and pathogenesis of gastritis and related complications.

To confirm our observations of increased hBDl and hBD2 expression by $H$ pylori in tissue culture cell lines, we analysed mRNA and peptide expression of both peptides in gastric biopsy specimens. Using semiquantitative RT-PCR, we found increased expression of hBDl and hBD2 in $H$ pylori mediated gastritis. As no hBD2 mRNA was detectable in control tissue, the increase observed in gastritis was found to be much greater than that observed for hBDl. Immunohistochemical analyses revealed a parallel increase in both hBDl and hBD2 peptide expression during bacterial induced inflammation. This pilot study on analyses of hBDl and hBD2 expression from human gastric biopsies suggests a potential role for these peptides in host innate defence to infection and inflammation.

$H$ pylori induced chronic inflammation is dependent on the persistence of the organism in the gastric antrum and/or fundus. Several factors such as the low immunological activity of
$H$ pylori lipopolysaccharide, ${ }^{31}$ bacterial expression of Lewis antigen, $^{32}$ interference with antigen processing and presentation, ${ }^{33}$ and increased expression of IL- $10^{34}$ have all been implicated in the increased colonisation and ineffective clearance of $H$ pylori from the gastric mucosa. The potential role and contribution of antimicrobial peptides at the surface of the gastric epithelium and their interactions with factors that favour colonisation of the bacterium are still unclear and warrant further investigation.

\section{ACKNOWLEDGEMENT}

Supported by the Special Trustees of St Bartholomew's and the Royal London School of Medicine and Dentistry (MBE).

\section{Authors' affiliations}

M Bajai-Elliott, P Fedeli, G V Smith, L Maher, Department of Adult and Paediatric Gastroenterology, St Bartholomew's and the Royal London School of Medicine and Dentistry, Turner St, London, UK

P Domizio, Department of Histopathology, St Bartholomew's and the Royal London School of Medicine and Dentistry, Turner St, London, UK R S Ali, A G Quinn, Centre for Cutaneous Research, St Bartholomew's and the Royal London School of Medicine and Dentistry, Turner St, London, UK

M J G Farthing, Faculty of Medicine, University of Glasgow, South Park Terrace, Glasgow G12 8LG, UK

\section{REFERENCES}

1 Kagnoff MF, Eckmann L. Epithelial cells as sensors for microbial infection. J Clin Invest 1997;100:6-10.

2 McKay DM, Baird AW. Cytokine regulation of epithelial permeability and ion-transport. Gut 1999;44:283-9.

3 Cover TL, Blaser M. Helicobacter pylori and gastroduodenal disease. Ann Rev Med 1992:43:135-45.

4 Bamford KB, Fan X, Crowe SE, et al. Lymphocytes in the human gastric mucosa during Helicobacter pylori have a T helper cell 1 phenotype. Gastroenterology 1998;114:482-92.

5 Fox JG, Beck P, Dangler CA, et al. Concurrent enteric helminth infection modulates inflammation and gastric immune responses and reduces Helicobacter-induced gastric atropy. Nat Med 2000;6:536-42.

6 Zhang QB, Etolhi G, Dawodu JB, et al. Relationship between mucosal levels of Helicobacter-pylori specific lgA, interleukin-8 and gastric inflammation. Clin Sci 1999:96:409-14.

7 Censini S, Lange C, Xiang Z, et al. cag, a pathogenicity island of Helicobacter pylori, encodes type l-specific and disease-associated virulence factors. Proc Natl Acad Sci USA 1996;93:14648-53.

8 Satin B, Del Giudice G, Della Bianca V, et al. The neutrophil-activating protein (HP-NAP) of Helicobacter pylori is a protective antigen and a major virulence factor. J Exp Med 2000;191:1467-76.

9 Allen LA. Modulating phagocyte activation: the pros and cons of Helicobacter pylori virulence factors. J Exp Med 2000;191:1451-4.

10 Zhao C, Wang I, Lehrer RI. Widespread expression of beta-defensin hBD- 1 in human secretory glands and epithelial cells. FEBS Lett 1996:396:319-22

11 Goldman MJ, Anderson GM, Stolzenberg ED, et al. Human $\beta$-Defensin-1 is a salt-sensitive antibiotic in lung that is inactivated in cystic fibrosis. Cell 1997:88:553-60.

12 Harder J, Bartels J, Christophers E, et al. A peptide antibiotic from human skin. Nature 1997;387:861.

13 Valore EV, Park CH, Quayle AJ, et al. Human $\beta$-defensin 1: An antimicrobial peptide of urogenital tissues. J Clin Invest 1998; 101:1633-42.

14 Diamond G, Bevins CL. $\beta$-Defensins: Endogenous antibiotics of the innate host defence response. Clin Immunol Immunopathol 1998;83:22 1-5.

15 O'Neil DA, Martin Porter E, Elewaut D, et al. Expression and regulation of the human beta-defensins hBD-1 and hBD-2 in intestinal epithelium. J Immunol 1999:163:6718-28.

16 Hiratsuka T, Nakazato M, Date Y, et al. Identification of human beta-defensin-2 in respiratory tract and plasma and its increase in bacterial pneumonia. Biochem Biphys Res Commun 1998;249:943-7.

17 Wada A, Mori N, Oishi K, et al. Induction of human beta-defensin 2 mRNA expression by Helicobacter pylori in human gastric cell line MKN45 cells on cag pathogenicity island. Biochem Bipohys Res Commun 1999;263:770-4.

18 O'Neil DA, Cole SP, Martin-Porter E, et al. Regulation of human $\beta$-defensins by gastric epithelial cells in response to infection with Helicobacter pylori or stimulation with interleukin-1. Infect Immun 2000;68:5412-15

19 Bajaj-Elliott $M$, Breese EJ, Poulsom R, et al. Keratinocyte growth factor in inflammatory bowel disease: increased mRNA transcripts in ulcerative colitis compared with Crohn's disease in biopsies and isolated mucosa myofibroblasts. Am J Pathol 1997;151:1469-76. 
20 Ali RS, Falconer A, Ikram $M$, et al. Expression of the peptide antibiotics human $\beta$-defensin 1 and human $\beta$-defensin 2 in normal human skin. J Invest Dermatol 2001;117:106-11.

21 Russell JP, Diamond G, Tarver AP, et al. Co-ordinate induction of two antibiotic genes in tracheal epithelial cells exposed to the inflammatory mediators lipopolysacchride and tumor necrosis factor-alpha. Infect Immun 1996;64:1565-8

22 Kuipers EJ. Helicobacter pylori and the risk and management of associated diseases: gastritis, ulcer disease, atrophic gastritis and gastric cancer. Aliment Pharmacol Ther 1997;11:71-88.

23 Crabtree JE. Gastric mucosal inflammatory responses to Helicobacter pylori. Aliment Pharmacol Ther 1996;10:29-37.

24 Sharma SA, Tummuru KR, Blaser M, et al. Activation of IL-8 gene expression by Helicobacter pylori is regulated by transcription facto nuclear $\kappa B$ in gastric epithelial cells. J Immunol 1998;160:2401-7.

25 Mori N, Wada A, Hirayama T, et al. Activation of intercellular adhesion molecule 1 expression by Helicobacter pylori is regulated by NF-KB in gastric epithelial cancer cells. Infect Immun 2000;68: 1806-14.

26 Dale BA, Kimball JR, Krisanaprakornkit S, et al. Localised antimicrobial peptide expression in human gingiva. J Periodont Res 2001;36:285-94.

27 Wada A, Ogushi K, Kimura T, et al. Helicobacter pylori-mediated transcriptional regulation of the human $\beta$-defensin 2 gene requires $N F \kappa B$. Cell Microbiol 2001;3:115-23.
28 Liu L, Zhao C, Heng HHQ, et al. The human beta-defensin-1 and alpha-defensins are encoded by adjacent genes: Genomics 1997;43:316-20.

29 Mathews M, Jia HP, Guthmiller JM, et al. Production of $\beta$-defensin antimicrobial peptides by the oral mucosa and the salivary glands. Infect Immun 1999;67:2740-5.

30 El-Omar EM, Carrington M, Chow WH, et al. Interleukin-1 polymorphisms associated with increased risk of gastric cancer. Nature 2000;404:398-402.

31 Moran AP. Cell surface characteristics of Helicobacter pylori. FEMS Immunol Med Microbiol 1995;10:271-80.

32 Heneghan MA, McCarthy CF, Moran AP. Relationship of blood group determinants on Helicobacter pylori lipopolysaccharide with host lewis phenotype and inflammatory response. Infect Immun 2000;68:937-41

33 Molinari M, Salio M, Galli C, et al. Selective inhibition of li-dependent antigen presentation by Helicobacter pylori toxin VacA. J Exp Med 1998; 187: 135-40.

34 Bauditz J, Ortner M, Beirbaum M, et al. Production of IL-12 in gastritis relates to infection with Helicobacter pylori. Clin Exp Immunol $1999 ; 117: 316-23$

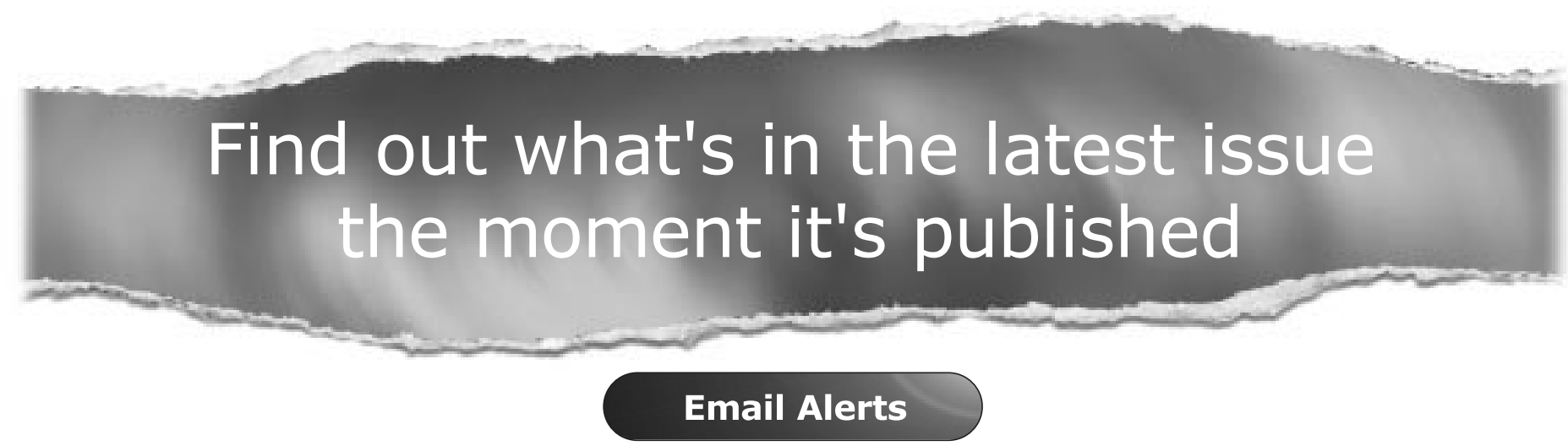

Sign up to receive the table of contents by email every month. You can select from three alerts: Table of Contents (full), TOC Awareness (notice only); Gut related announcements.

\section{www.gutjnl.com}

